\title{
Efficacy of Ramosetron in Male Patients With Irritable Bowel Syndrome With Diarrhea
} (Neurogastroenterol Motil 2011;23:1098-1104)

\author{
Bong Ki Cha, ${ }^{1,2}$ Chang Hwan Choi ${ }^{2 *}$ and Sae Kyung Chang ${ }^{2}$ \\ ${ }^{1}$ Department of Internal Medicine, Hyundae Hospital, Namyangju, Gyeonggi-do, Korea; and ${ }^{2}$ Department of Internal Medicine, Chung-Ang \\ University College of Medicine, Seoul, Korea
}

\section{Summary}

Serotonin (5-Hydroxytryptamine [5-HT]) plays an important role in gastrointestinal (GI) motility and sensation, and abnormal levels have been shown in patients with irritable bowel syndrome (IBS). ${ }^{1,2}$ Drugs acting on 5-HT receptors have the potential to reduce the smooth muscle spasm, abdominal pain, and changes in bowel habit in IBS.

Recently, Lee et $\mathrm{al}^{3}$ assessed the efficacy and safety of ramosetron, a $5-\mathrm{HT}_{3}$ receptor antagonist, compared with mebeverine in male patients with diarrhea-predominant IBS (IBS-D). This study was performed in a multicenter, randomized, open-label, parallel-group, non-inferiority comparative design. A total of 343 male patients with IBS-D were randomized to either ramosetron $5 \mu \mathrm{g}$ once daily or mebeverine $135 \mathrm{mg} 3$ times daily for 4 weeks.

The weekly responder rates for global IBS symptoms, abdominal pain/discomfort and abnormal bowel habits in the ramosteron and mebeverine groups significantly increased during the treatment period $(\mathrm{P}<0.001)$. The severity scores of abdominal pain/discomfort and urgency, the stool form scores and the stool frequency recorded daily were reduced significantly in both treatment arms, compared with the baselines $(P<0.001)$. There were no significant differences in the weekly responder rates ( $37 \%$ vs $38 \%$ at 4 -week) and in the adverse event profiles between the ramosetron and mebeverine groups. Neither severe constipation nor ischemic colitis was reported. The authors concluded that the ramosetron $5 \mu \mathrm{g}$ once daily was as effective as mebeverine 3 times daily in male patients with IBS-D.

\section{Comment}

IBS is the most common functional bowel disorder and is characterized by recurrent abdominal pain and discomfort with altered bowel habits. ${ }^{4}$ IBS may lead to impaired social and personal functions as well as deterioration in the quality of life of affected individuals. While the pathophysiology of IBS is still unclear, altered bowel motility, visceral hypersensitivity, immune activation, enteric neuromuscular dysfunction, abnormal brain-gut interactions, and alteration in the gut microbiome have been hypothesized. ${ }^{5}$ Although the concept of IBS has been established for several decades, current available therapies remain unsatisfactory and provide only symptomatic relief at best for many patients with IBS.

Received: March 15, 2012 Revised: March 20, 2012 Accepted: March 25, 2012

(c) This is an Open Access article distributed under the terms of the Creative Commons Attribution Non-Commercial License (http://creativecommons. org/licenses/by-nc/3.0) which permits unrestricted non-commercial use, distribution, and reproduction in any medium, provided the original work is properly cited.

*Correspondence: Chang Hwan Choi, MD, PhD

Department of Internal Medicine, Chung-Ang University College of Medicine, Heukseok-ro 102, Dongjak-gu, Seoul 156-755, Korea

Tel: +82-2-6299-1418, Fax: +82-2-6299-2017, E-mail: gicch@cau.ac.kr

Financial support: None.

Conflicts of interest: None. 
Serotonin (5-HT) signaling in the GI tract is known to control a range of functions such as motility, sensation and secretion. ${ }^{1,2}$ Some evidence suggests that drugs regulating the 5-HT signaling are effective in patients with IBS. ${ }^{6-9}$ Alosetron, a 5- $\mathrm{HT}_{3}$ antagonist, was first evaluated in the 1990s, and initial trial data suggested that it was a promising drug for the treatment of IBS-D, particularly in female patients. However, because of the serious adverse events, such as severe constipation and ischemic colitis, reported in IBS patients treated with alosetron, it is available only in the USA with a limited access program for women with severe IBS-D refractory to conventional therapy. ${ }^{10}$ Recently, ramosetron, one of the $5-\mathrm{HT}_{3}$ receptor antagonists, have been reported to be effective for patients with IBS-D in 2 clinical trials. $^{11,12}$ The administration of ramosetron $5 \mu \mathrm{g}$ once daily had beneficial effects on IBS symptoms of male patients with IBS-D, compared with placebo.

Lee et $\mathrm{al}^{3}$ assessed the efficacy of ramosetron compared with mebeverine, an antispasmodic agent, in male patients with IBS-D. Ramosetron had similar therapeutic efficacy to mebeverine and the adverse event profiles of the ramosetron group were comparable with those of the mebeverine. ${ }^{3}$

Since IBS is defined as abdominal pain or discomfort that is improved with defecation, ${ }^{13}$ the US Food and Drug Administration (FDA) requested to evaluate the 2 major IBS symptoms: abdominal pain and defecation in IBS trials. Abdominal pain intensity was recommended as the primary pain assessment and to be evaluated on a daily basis. For defecation component, the assessment of stool frequency was encouraged for IBS-C and stool consistency for IBS-D. ${ }^{14,15}$ In the present study, the primary efficacy parameter was the patient-reported relief of IBS symptoms, including abdominal pain/discomfort and abnormal bowel habits, and the secondary endpoints were the changes in each symptom score. The IBS symptom scores and stool consistency were recorded daily throughout the study periods, and the changes of weekly mean scores were analyzed. This study is considered as a well-designed clinical study that was amenable to the proposal of the FDA for IBS clinical trials.

However, the present study had several limitations. First, because this study was not a placebo-controlled trial, the exact efficacy of ramosetron over placebo was not evaluated. The FDA proposed that clinical studies need to be randomized and placebo-controlled to adequately assess IBS treatment benefits. ${ }^{14,15}$ Futhermore, mebeverine, the control agent in this study, showed no statistically significant benefit compared with placebo for global improvement of IBS symptoms in recent systematic reviews. ${ }^{16-18}$ Thus, randomized placebo-controlled studies are necessary to estimate the exact effects of ramosetron in patients with IBS-D. Second, as the authors mentioned in discussion, because a tablet of ramosetron was taken once daily and a tablet of mebeveine was taken 3 times daily, the psychological effects might be greater in the patients who received mebeverine. Finally, this study was conducted for a short period and used only one dose of ramosetron. Further studies to evaluate the long-term effects of ramosetron and whether twice daily administration of a ramosetron $5 \mu \mathrm{g}$ tablet has greater efficacy in patients with IBS-D are needed.

Although several limitations exist, the present study is a well-designed, randomized clinical trial to assess the efficacy and safety of $5 \mu \mathrm{g}$ ramosetron in male patients with IBS-D. Ramosetron can be used safely for the relief of IBS symptoms in male with IBS-D. Further studies on whether ramosetron is effective for female patients with IBS-D are warranted.

\section{References}

1. Gershon MD. Review article: roles played by 5 -hydroxytryptamine in the physiology of the bowel. Aliment Pharmacol Ther 1999;13 (suppl 2):15-30.

2. Gershon MD, Tack J. The serotonin signaling system: from basic understanding to drug development for functional GI disorders. Gastroenterology 2007;132:397-414.

3. Lee KJ, Kim NY, Kwon JK, et al. Efficacy of ramosetron in the treatment of male patients with irritable bowel syndrome with diarrhea: a multicenter, randomized clinical trial, compared with mebeverine. Neurogastroenterol Motil 2011;23:1098-1104.

4. Drossman DA, Camilleri M, Mayer EA, Whitehead WE. AGA technical review on irritable bowel syndrome. Gastroenterology 2002;123:2108-2131.

5. Hasler WL. Traditional thoughts on the pathophysiology of irritable bowel syndrome. Gastroenterol Clin North Am 2011;40:21-43.

6. Camilleri M, Northcutt AR, Kong S, Dukes GE, McSorley D, Mangel AW. Efficacy and safety of alosetron in women with irritable bowel syndrome: a randomised, placebo-controlled trial. Lancet 2000;355:1035-1040.

7. Cremonini F, Delgado-Aros S, Camilleri M. Efficacy of alosetron in irritable bowel syndrome: a meta-analysis of randomized controlled trials. Neurogastroenterol Motil 2003;15:79-86.

8. Ford AC, Brandt LJ, Young C, Chey WD, Foxx-Orenstein AE, Moayyedi P. Efficacy of 5- $\mathrm{HT}_{3}$ antagonists and $5-\mathrm{HT}_{4}$ agonists in irritable bowel syndrome: systematic review and meta-analysis. Am J Gastroenterol 2009;104:1831-1843.

9. Krause R, Ameen V, Gordon SH, et al. A randomized, double-blind, placebo-controlled study to assess efficacy and safety of $0.5 \mathrm{mg}$ and 1 $\mathrm{mg}$ alosetron in women with severe diarrhea-predominant IBS. Am J Gastroenterol 2007;102:1709-1719.

10. Chang L, Chey WD, Harris L, Olden K, Surawicz C, Schoenfeld P. 
Incidence of ischemic colitis and serious complications of constipation among patients using alosetron: systematic review of clinical trials and post-marketing surveillance data. Am J Gastroenterol 2006;101: 1069-1079.

11. Matsueda K, Harasawa S, Hongo M, Hiwatashi N, Sasaki D. A phase II trial of the novel serotonin type 3 receptor antagonist ramosetron in Japanese male and female patients with diarrhea-predominant irritable bowel syndrome. Digestion 2008;77:225-235.

12. Matsueda K, Harasawa S, Hongo M, Hiwatashi N, Sasaki D. A randomized, double-blind, placebo-controlled clinical trial of the effectiveness of the novel serotonin type 3 receptor antagonist ramosetron in both male and female Japanese patients with diarrhea-predominant irritable bowel syndrome. Scand J Gastroenterol 2008; 43:1202-1211.

13. Longstreth GF, Thompson WG, Chey WD, Houghton LA, Mearin F, Spiller RC. Functional bowel disorders. Gastroenterology 2006;130:1480-1491.

14. Food and Drug Administration Center for Drug Evaluation and Research (CDER) and Center for Biologics Evaluation and Re- search (CBER). Guidance for industry: irritable bowel syndrome: clinical evaluation of products for treatment, March 2010. Available from URL: http://www.fda.gov/downloads/Drugs/ GuidanceCompliance Regulatory Information/Guidances/UCM205269.pdf (accessed 19 March, 2012).

15. Trentacosti AM, He R, Burke LB, Griebel D, Kennedy DL. Evolution of clinical trials for irritable bowel syndrome: issues in end points and study design. Am J Gastroenterol 2010;105:731-735.

16. Darvish-Damavandi M, Nikfar S, Abdollahi M. A systematic review of efficacy and tolerability of mebeverine in irritable bowel syndrome. World J Gastroenterol 2010;16:547-553.

17. Ford AC, Talley NJ, Spiegel BM, et al. Effect of fibre, antispasmodics, and peppermint oil in the treatment of irritable bowel syndrome: systematic review and meta-analysis. BMJ 2008;337:A2313.

18. Ruepert L, Quartero AO, de Wit NJ, van der Heijden GJ, Rubin G, Muris JW. Bulking agents, antispasmodics and antidepressants for the treatment of irritable bowel syndrome. Cochrane Database Syst Rev 2011;(8):CD003460. 